\title{
Mendeteksi Penyakit Cabai Keriting Dengan Metode Certainty Factor
}

\author{
Ahmad Fahrurohim ${ }^{1)}$; Sri Siswanti ${ }^{2)}$; Bebas Widada ${ }^{3)}$ \\ ${ }^{1,2)}$ Program Studi Teknik Informatika, STMIK Sinar Nusantara Surakarta \\ 3) Program Studi Sistem Informasi, STMIK Sinar Nusantara Surakarta \\ 1)amethmjhc561@gmail.com; ${ }^{2)}$ syswanty@sinus.ac.id; ${ }^{3}$ bbswdd@sinus.ac.id
}

\begin{abstract}
The disease of kinky chili plants often got plant diseases, such as brown spots on its leaves, wither Fusarium, Wilt bacteria, and rotten leaves. This disease often affects these kinky chili plants that can harm farmers like failing plants and can cause plants to die. The purpose of this research is to design an application used to diagnose diseases in curly chili peppers. Therefore, the method of Certainty Factors in this research can figure out the type of plant diseases in curly chili peppers because this method is used to overcome uncertainty in decision making by measuring the facts or rules. Data collection includes interviews with an expert so the data can be trusted. To reinforce the research, the information of this analysis can be added by reading book journals, books and literature in the library and online. Steps to make an implementation of the method of Certainty Factor in detecting curly chili disease are designed to design concepts, collect data, prepare hardware and software, create an application creation diagram modeling, testing, repair, and resolution. Based on the testing of BlackBox in the system, this system is well-functioned according to user commands. In addition, the targeted testing of the validity of manual calculations and system calculations is valid with $93.77 \%$ true percentage value.
\end{abstract}

Keywords: Certainty Factor, Disease Detection, Curly Chili Plants

\section{PENDAHULUAN}

Permasalahan yang dialami oleh kelompok tani adalah tanaman pada cabai keriting lebih mudah terserang penyakit di banding jenis cabai yang lain, selain itu cabai keriting ini tingkat pemasarannya paling tinggi. Permasalahan yang dihadapi petani cabai adalah kurangnya pengetahuan petani tentang penyakit tanaman cabai keriting, sehingga perlu adanya suatu sistem yang dapat digunakan petani dalam mendeteksi penyakit yang ada di tanaman cabai keriting. Penyakit yang sering ditemui dalam tanaman cabai keriting adalah Busuk Daun, Layu Bakteri, Layu Fusarium, Bercak Coklat pada Daun. Penyakit yang ada di tanaman cabai keriting tersebut dapat menyebabkan tanaman mati, sehingga petani rugi karena gagal panen.

Tujuan penelitian adalah bagaimana metode Certainty Factor mendeteksi penyakit pada tanaman cabai keriting.Sistem pakar dengan menggunakan metode Certainty Factor hasilnya seperti layaknya diagnose seorang pakar hal ini terjadi pada kasus untuk mendiagnosa hama dan penyakit tanaman cabai besar[1].

Pada penelitian untuk mendeteksi hama pada tanaman cabe menggunakan CF, menghasilkan aplikasi expert system yang dapat digunakan oleh petani untuk konsultasi mengenai gejala hama penyakit, sehingga petani mendapat jawaban dan juga tips untuk mengatasi masalah. Aplikasi ini dapat digunakan oleh petani sebagai antisipasi dan penanggulangan dini dalam mengatasi masalah penyakit pada tanaman cabai [2].

\section{TINJUAN PUSTAKA}

Faktor kepastian (certainty factor) diperkenalkan oleh Shorliffe Buchanan dalam pemebuatan MYCIN. Certainty Factor (CF) merupakan nilai paremeter klinis yang diberikn MYCIN utuk menunjukan besarnya kepercayaan[3].

Faktor kepastian mempunyai rumus dasar:

$\mathrm{CF}(\mathrm{H}, \mathrm{E})=\mathrm{MB}(\mathrm{H}, \mathrm{E})-\mathrm{MD}(\mathrm{H}, \mathrm{E})$

$\mathrm{CF}$ [user] ${ }^{*} \mathrm{CF}[$ pakar]

Certainty Factor untuk kaidah dengan kesimpulan yang serupa (similary concluded rules)

CFcombine $\mathrm{CF}[\mathrm{H}, \mathrm{E}] 1,2=\mathrm{CF}[\mathrm{H}, \mathrm{E}] 1+\mathrm{CF}[\mathrm{H}, \mathrm{E}] 2{ }^{*}[1$ - $\mathrm{CF}[\mathrm{H}, \mathrm{E}] 1]$

Cfcombine $\mathrm{CF}[\mathrm{H}, \mathrm{E}]$ old, $3=\mathrm{CF}[\mathrm{H}, \mathrm{E}]$ old $+\mathrm{CF}[\mathrm{H}, \mathrm{E}] 3$ *

[1CF[H,E]old][4].

$\mathrm{CF}_{\text {persentase }}=\mathrm{CF}_{\text {combine }}{ }^{*} 100 \%$

Keterangan :

$\mathrm{CF}(\mathrm{H}, \mathrm{E})$ : Certainty factor dari hipotesis $\mathrm{H}$ yang dipengaruhi oleh gejala (evidence) $\mathrm{E}$. Besarnya CF berkisar antara -1 sampai 
dengan 1. Nilai -1 menunjukkan ketidakpercayaan mutlak sedangkan nilai 1 menunjukkan kerpercayaan mutlak.

$\mathrm{MB}(\mathrm{H}, \mathrm{E})$ : Ukuran kenaikan kepercayaan (measure of increased belief) terhadap hipotesis $\mathrm{H}$ yang dipengaruhi oleh gejala $\mathrm{E}$.

$\mathrm{MD}(\mathrm{H}, \mathrm{E})$ : Ukuran kenaikan ketidakpercayaan (measure of increased disbelief) terhadap hipotesis $\mathrm{H}$ yang dipengaruhi oleh gejala $\mathrm{E}$.

Nilai keprcayaan didapatkan dari interperensi seorang pakar yang kemudian dirubah/dikonvensi menjadi nilai kepercayaan dengan ketentuan seperti tabel pada Tabel 1.

Tabel 1. Nilai evidence tingkat kayakinan pakar

\begin{tabular}{|l|l|}
\hline Certainty Term & Nilai CF \\
\hline Pasti Tidak & $-1,0$ \\
\hline Hampir Pasti Tidak & $-0,8$ \\
\hline Kemungkinan Besar Tidak & $-0,6$ \\
\hline Mungkin Tidak & $-0,4$ \\
\hline Tidak Tahu & $-0,2$ to 0,2 \\
\hline Mungkin & 0,4 \\
\hline Kemungkinan Besar & 0,6 \\
\hline Hampir Pasti & 0,8 \\
\hline Pasti & 1,0 \\
\hline
\end{tabular}

Matriks dan gejala penyakit yang digunakan untuk mendiagnosis penyakit pada cabai kriting seperti pada Tabel 2.

Tabel 2. Matrik dan Gejala

\begin{tabular}{|l|l|l|l|l|}
\hline \multirow{2}{*}{ Gejala } & \multicolumn{4}{|l|}{ Penyakit } \\
\hline & P1 & P2 & P3 & P4 \\
\hline G01 & ${ }^{*}$ & & & ${ }^{*}$ \\
\hline G02 & ${ }^{*}$ & ${ }^{*}$ & ${ }^{*}$ & \\
\hline G03 & & ${ }^{*}$ & & \\
\hline G04 & & ${ }^{*}$ & ${ }^{*}$ & \\
\hline G05 & & ${ }^{*}$ & ${ }^{*}$ & \\
\hline G06 & ${ }^{*}$ & & & ${ }^{*}$ \\
\hline G07 & ${ }^{*}$ & ${ }^{*}$ & ${ }^{*}$ & ${ }^{*}$ \\
\hline G08 & ${ }^{*}$ & & & \\
\hline G09 & & & ${ }^{*}$ & ${ }^{*}$ \\
\hline
\end{tabular}

Keterangan Penyakit :

P1 : Busuk Daun

P2 : Layu Bakteri

P3 : Layu Fusarium

P4 : Bercak Coklat pada Daun

Keterangan Gejala :

G01 : Daun Bercak Coklat

G02 : Daun tua menguning

G03 : Daun muda layu

G04 : Tulang Daun berwarna putih

G05 : Tangkai daun merunduk

G06 : Bawah Daun Bercak Putih

G07 : Batang Berwarna Coklat
G08 : Batang atas mengering

G09 : Tanaman Layu Keseluruhan

Berdasarkan hasil pengujian pada penelitian sistem pakar yang digunakan untuk mendiaknosa penyakit pada tanaman padi dengan menggunakan 15 kasus yang berbeda dengan yang ada dilapangan kemudian di cross check dengan hasil Analisa pakar memiliki kesesuaian sebanyak $93 \%$ [5].

Berdasarkan hasil penelitia diagnose terhadao tanaman tebu dengan metode certainty factor, menhasilkan tingkat nilai akurasi 94,6 \%. Pengukuran yang dilakukan terhadap nilai kepastian dari suatu hipotesa dengan suatu fakta yaitu dengan menggunakan metode Certainty Factor [6].

Gejala yang diderita batuk kering, Dahak kental dan kuning, Sesak nafas restrotenal, suara ada lendir, suara nafas berderak, akurasi sistem yang diusulkan mencapai $99 \%$. Selain itu sistem pakar juga diterapkan dalam mengetahui hama wereng untuk tanaman padi [7].

Metode Certainty Factor cocok untuk penentuan identifikasi hama dan penyakit yang menyerang pada tanaman tembakau. Pemilihan gejala yang mempengaruhi penyakit pada tembakau, kemudian diperoleh persentase hasil konsultasi. Hasil Persentasi tertinggi peratama dan kedua, sebagai alternatif dari penyakit yang menyerang tanaman tembakau. Proses konsultasi yang dilakukan user sehingga mendapatkan hasil data penyakit dalam bentuk persentase, nilai tertinggi yang dicapai ialah $99.985729744 \%$ [8].

Pada penelitian [9], berdasarkan faktafakta yang ada dengan memanfaakan Forward Chaining sebagai mesin inferensi selanjutnya dihitung dengan metode Dempster- Shafer. Hasil pengujian yang dilakukan dengan mengukur tingkat akurasi hasilnya sebesar 90\%, sehingga metode Forward Chaining dan Dempster-Shafer dapat diterapkan untuk mendiagnosis penyakit tanaman tomat.

\section{METODE PENELITIAN}

Perancangan Penerapan metode Certainty Factor dalam mendeteksi pada penyakit cabai keriting ada beberapa metode penelitian yang dilakukan, di antaranya :

a. Metode Pengumpulan Data

Penelitian ini menggunakan data primer dan data sekunder. Data primer berupa penyakit, gejala beserta saran yang dapat dilakukan petani, diperoleh dari hasil 
wawancara oleh pakar. Sedangkan data sekunder diperoleh dari studi pustaka berupa jurnal ilmiah/literature.

b. Analisa dan Desain Sistem

Pada tahap analis peneliti menentukan kebutuhan sistem mulai dari hardware, software, user pengguna data base yang digunakan. Tahap desain sistem yang digunakan dalam perancangan sistem ini berbasis terstruktur.

c. Pembuatan Program

Tahapan yang dilakukan setelah tahap desain sistem dibuat.

Pengaplikasian kode program dengan metode Certainty Factor sehingga menghasilkan sistem yang dapat mendeteksi penyakit cabai keriting.

d. Pengujian

Pengujian dilakukan 2 tahap, yang pertama uji fungsionalitas dengan blackbox untuk mengetahui sistem dapat berjalan baik atau tidak. Kedua adalah uji validitas yang dilakukan oleh pakar terkait untuk menguji apakah sistem ini sudah layak digunakan.

\section{HASIL DAN PEMBAHASAN}

\subsection{Diagram Context}

Diagram Context pada sistem pendeteksi pada penyakit cabai keriting ditunjukkan pada Gambar 1.

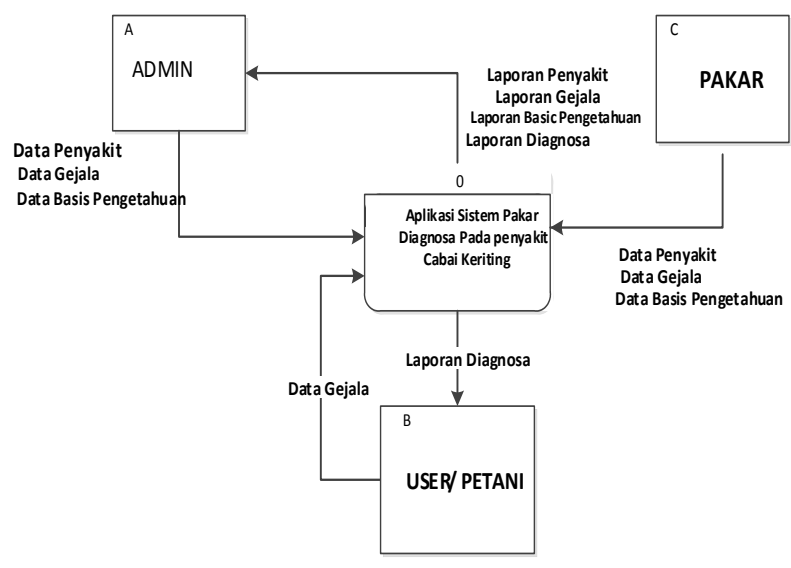

\section{Gambar 1. Diagram Context}

\subsection{Diagaram Data Level 0}

Pada Gambar 2 Diagram Arus Data level 0 berisi tentang input, output secara global dan terjadi arus data berupa data penyakit, data gejala, dan data berbasis pengetahuan dan hasil diagnosa.

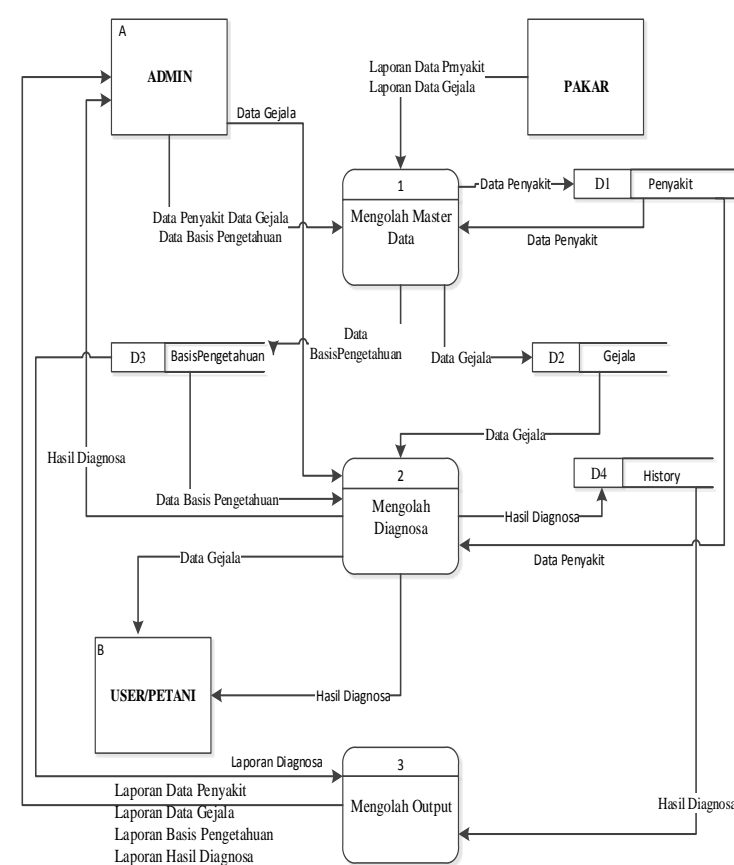

Gambar 2. Diagram Arus Data Level 0

\subsection{Entity Relationship Diagram (ERD)}

ERD seperti pada Gambar 3 dibuat untuk menghubungkan antar entitas yang digunakan dalam membangun sistem ini.

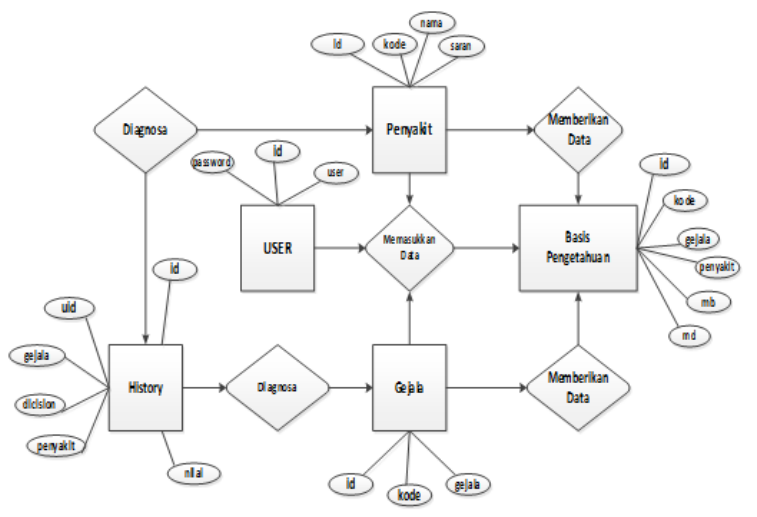

Gambar 3. ERD

\subsection{Perubahan Certainty Factor}

Perubahan Cetainty Factor membahas perhitungan dalam mendeteksi penyakit pada tanaman cabai keriting dengan metode Certainty Factor. Tabel 3 berikut ini adalah nilai CF pakar pada masing-masing gejala dengan menggunakan rumus (1) Rumus dasar faktor kepastian

Tabel 3. Daftar Nilai CF Pakar

\begin{tabular}{|l|l|l|l|}
\hline No & Gejala & $\begin{array}{l}\text { Busuk } \\
\text { Daun }\end{array}$ & Layu Bakteri \\
\hline 1. & $\begin{array}{l}\text { Daun tua } \\
\text { menguning }\end{array}$ & $\begin{array}{l}0,8-0,2 \\
=0,6\end{array}$ & $1,0-0,2=0,8$ \\
\hline 2. & $\begin{array}{l}\text { Daun muda } \\
\text { layu }\end{array}$ & - & $0,8-0,2=0,6$ \\
\hline 3. & $\begin{array}{l}\text { Tulang daun } \\
\text { berwarna putih }\end{array}$ & - & $1,0-0,2=0,8$ \\
\hline 4. & $\begin{array}{l}\text { Batang } \\
\text { berwarna }\end{array}$ & $\begin{array}{l}1,0-0,2 \\
=0,8\end{array}$ & $0,8-0,2=0,6$ \\
\hline
\end{tabular}




\begin{tabular}{|c|c|c|c|}
\hline No & Gejala & $\begin{array}{l}\text { Busuk } \\
\text { Daun }\end{array}$ & Layu Bakteri \\
\hline & coklat & & \\
\hline 5. & $\begin{array}{l}\text { Tanaman layu } \\
\text { keseluruhan }\end{array}$ & - & - \\
\hline No & Gejala & $\begin{array}{l}\text { Layu } \\
\text { Fusarium }\end{array}$ & $\begin{array}{l}\text { Bercak } \\
\text { Coklat pada } \\
\text { Daun }\end{array}$ \\
\hline 1. & $\begin{array}{l}\text { Daun tua } \\
\text { menguning }\end{array}$ & $\begin{array}{l}0,6-0,2 \\
=0,4\end{array}$ & \\
\hline 2. & $\begin{array}{l}\text { Daun muda } \\
\text { layu }\end{array}$ & - & \\
\hline 3. & $\begin{array}{l}\text { Tulang daun } \\
\text { berwarna putih }\end{array}$ & $\begin{array}{ll}1,0 & -0,2 \\
=0,8 & \end{array}$ & \\
\hline 4. & $\begin{array}{l}\text { Batang } \\
\text { berwarna } \\
\text { coklat }\end{array}$ & $\begin{array}{l}0,8-0,2 \\
=0,6\end{array}$ & $1,0-0,2=0,8$ \\
\hline 5. & $\begin{array}{l}\text { Tanaman layu } \\
\text { keseluruhan }\end{array}$ & $\begin{array}{l}1,0-0,2 \\
=0,8\end{array}$ & $0,8-0,2=0,6$ \\
\hline
\end{tabular}

\subsection{Implementasi}

Pada halaman utama terdapat halaman untuk mengakses sistem. Halaman utama yang memuat form login yang harus diisi terlebih dahulu oleh admin dengan memasukkan username dan password untuk login. Pada halaman Admin terdapat menu standar. Untuk mengelola database yang tentunya hanya mampu diakses oleh admin yang sudah melakukan login.

Setelah melakukan login maka admin bisa mengakses pengolahan data pada sistem tersebut. Administrator melakukan pengolahan data penyakit, data gejala, dan data basis pengetahuan.

Pada menu diagnosa user/petani bisa melakukan diagnosa penyakit pada tanaman cabai keriting seperti pada Gambar 4.

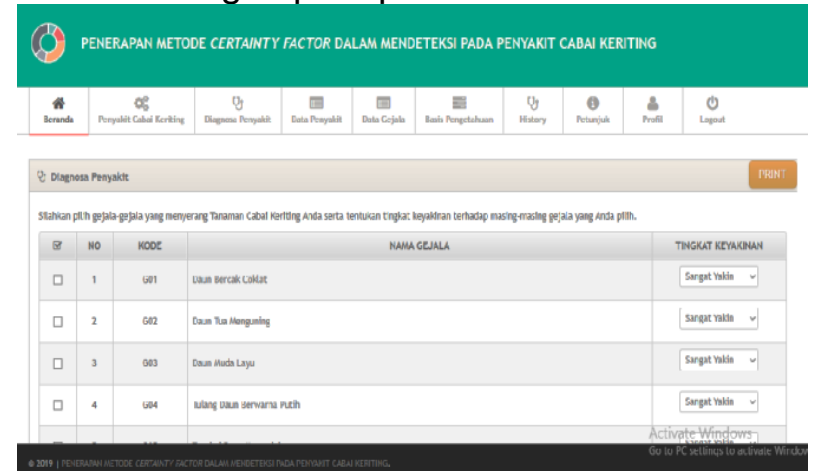

Gambar 4. Menu Diagnosa penyakit

Setelah memilih gejala dan menentukan nilai keyakinannya selanjutnya pilih diagnosa akan muncul hasil diagnosa seperti Gambar 5.

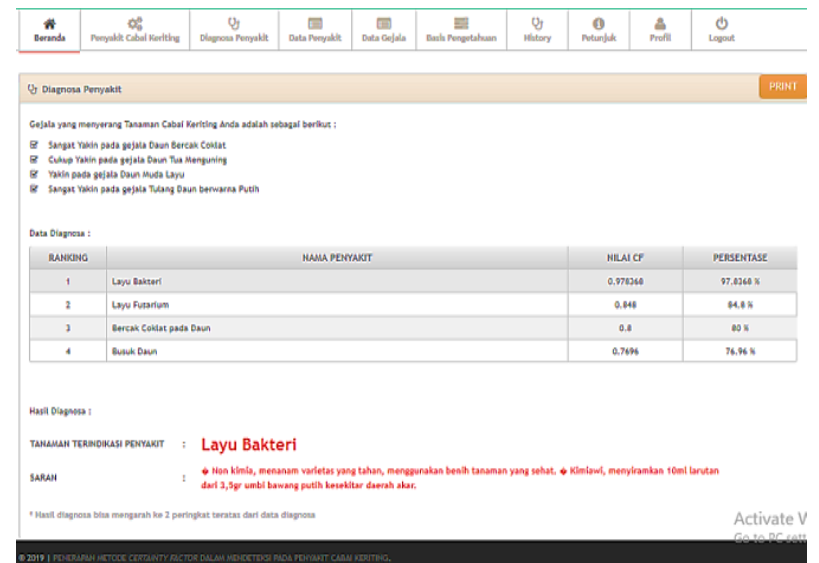

Gambar 5. Hasil Diagnosa Penyakit

Setelah melakukan diagnosa hasil akan disimpan dalam menu history seperti pada Gambar 6.

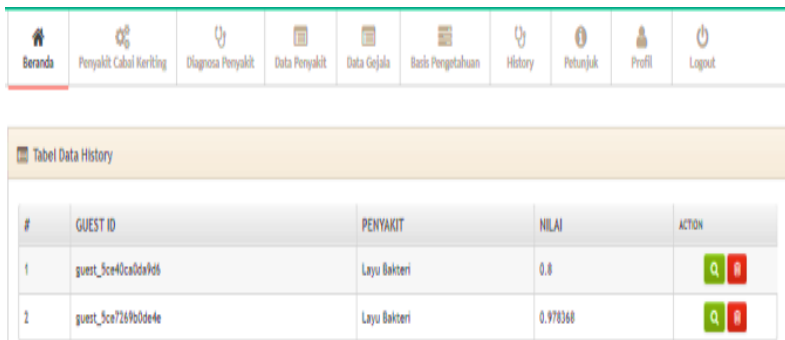

\section{Gambar 6. History Diagnosa}

\subsection{Pengujian Sistem}

\section{a. Pengujian Fungsional}

Pengujian fungsional pada sistem dilakukan dengan menggunakan Blackbox sistem. Pengujian fungsional dilkukan pada fungsi login, fungsi input data basis pengetahuan, serta dignosa penyakit. Sistem dapat melakukan perintah dari user dengan baik. Maka, berdasarkan dari pengujian blackbox sistem dinyatakan berfungsi sesuai dengan perintah yang diinput user. Berikut kasus Cabai keriting dengan gejala.

- Daun tua menguning

- Daun muda layu

- Tulang Daun berwarna putih

- Batang Berwarna Coklat

- Tanaman layu Keseluruhan

Proses perhitungan manual :

1. Menentukan Kaidah produksi dari masingmasing premis.

Kaidah 1 :

IF daun tua menguning AND Batang berwarna coklat THEN Busuk Daun

Kaidah 2 :

IF Daun tua menguning

AND Daun muda layu

AND Tulang daun berwarna putih

AND Batang berwarna coklat 
Kaidah 3

THEN Layu Bakteri

IF Daun tua menguning

AND Tulang daun berwarna coklat

AND Batang berwarna coklat

AND Tanaman layu keseluruhan

Kaidah 4 :

THEN Layu Fusarium

IF Batang berwarna coklat

AND Tanaman layu keseluruhan

THEN Bercak Coklat Pada Daun

2. Bobot CF User terhadap gejala /Daftar Nilai Keyakinan.

Bobot CF user terhadap gejala penyakit dan nilai keyakinan seperti pada Tabel 4.

Tabel 4. Bobot CF User

\begin{tabular}{|l|lr|}
\hline Daftar Gejala & \multicolumn{2}{|l|}{ Nilai Keyakinan } \\
\hline $\begin{array}{l}\text { Daun Tua } \\
\text { Menguning. }\end{array}$ & Cukup Yakin $\quad(0,6)$ \\
\hline Daun Muda Layu & Yakin & $(0,8)$ \\
\hline $\begin{array}{l}\text { Tulang Daun } \\
\text { Berwarna Putih. }\end{array}$ & Yakin & $(0,8)$ \\
\hline $\begin{array}{l}\text { Batang Berwarna } \\
\text { Coklat }\end{array}$ & Cukup Yakin $\quad(0.6)$ \\
\hline $\begin{array}{l}\text { Tanaman Layu } \\
\text { Keseluruhan }\end{array}$ & Cukup Yakin $\quad(0,6)$ \\
\hline
\end{tabular}

3. Memberikan bobot CF Pakar untuk masing-masing gejala.

Daftar nilai CF pakar seperti pada Tabel 3.

4. Memecahkan rule/kaidah menjadi premis tunggal :

a. Penyakit Busuk Daun

Kaidah 1.1:

IF Daun tua menguning THEN Busuk Daun

Kiadah 1.2 :

IF Batang berwarna coklat THEN Busuk Daun

b. Penyakit Layu Bakteri

Kaidah 2.1:

IF Daun tua menguning THEN Layu Bakteri

Kiadah 2.2 :

IF Daun muda layu THEN Layu Bakteri

Kiadah 2.3 :

IF Tulang bdaun berwarna putih THEN Layu Bakteri

Kaidah 2.4 :

IF Batang berwarna coklat THEN Layu Bakteri

c. Penyakit Layu Fusarium

Kaidah 3.1:

IF Daun tua menguning THEN Layu Fusarium

Kaidah 3.2 :

IF Tulang daun berwarna putih THEN Layu Fusarium

Kaidah 3.3 :

IF Batang berwarna coklat THEN Layu Fusarium

Kaidah 3.4 :
IF Tanaman Layu Keseluruhan THEN Layu Fusarium

d. Penyakit Bercak coklat pada daun

Kaidah 4.1:

IF Batang berwarna coklat

THEN Bercak coklat pada daun

Kaidah 4.2 :

IF Tanaman layu keseluruhan THEN Bercak coklat pada daun

5. Menghitung rule/kaidah hasil pecahan dari premis majemuk.

Menghitung nilai CF dengan menggunakan rumus (2):

Kaidah $1.1: 0,6 * 0,6=0,36$

Kaidah $1.2: 0,6{ }^{*} 0,8=0,48$

Kaidah $2.1: 0,6 * 0,8=0,48$

Kaidah $2.2: 0,8 * 0,6=0,48$

Kaidah $2.3: 0,8 * 0,8=0,64$

Kaidah $2.4: 0,6 * 0,6=0,36$

Kaidah $3.1: 0,6 * 0,4=0,24$

Kaidah $3.2: 0,8 * 0,8=0,64$

Kaidah $3.3: 0,6{ }^{*} 0,6=0,36$

Kaidah $3.4: 0,6 * 0,8=0,48$

Kaidah $4.1: 0,6 * 0,8=0,48$

Kaidah $4.2: 0,6 * 0,6=0,36$

6. Perhitungan CF kombinasi untuk semua rule. Perhitungan nilai ini menggunakan rumus (3).

a) Penyakit Busuk Daun

Perhitungan Kombinasi pada Penyakit

Busuk Daun dari Gejala Daun Tua Menguning dengan nilai kepercayaan 0,36 dan Daun muda layu dengan nilai kepercayaan 0,48. Dari gejala diatas pada penyakit Busuk Daun menghasilkan perhitungan kombinasi dengan menggunakan rumus sebagai berikut

$$
\begin{aligned}
\mathrm{CF}_{\text {combine }} & =\mathrm{CF}_{\text {old }}+\mathrm{CF}_{\text {gejala }}{ }^{*}\left(1-\mathrm{CF}_{\text {old }}\right) \\
\mathrm{CF}_{\text {combine }} & =0,36+0,48 *(1-0,36) \\
& =0,36+0,3072 \\
& =0,6672
\end{aligned}
$$

Hasil akhir untuk penyakit Busuk Daun

b) Layu Bakteri

Perhitungan Kombinasi pada Penyakit Layu Bakteri dari Gejala Daun Tua Menguning dengan nilai kepercayaan 0,48 ; Daun muda layu dengan nilai kepercayaan 0,48; Tulang daun berwarna putih dengan nilai kepercayaan 0,64 ; dan Batang berwarna coklat dengan nilai kepercayaan 0,36 Dari gejala-gejala diatas pada penyakit Layu Bakteri menghasilkan perhitungan kombinasi dengan menggunakan rumus sebagai berikut:

$$
\begin{aligned}
\mathrm{CF}_{\text {combine }} & =\mathrm{CF}_{\text {old }}+\mathrm{CF}_{\text {gejala }}{ }^{*}\left(1-\mathrm{CF}_{\text {old }}\right) \\
\mathrm{CF}_{\text {combine }} & =0,48+0,48^{*}(1-0,48) \\
& =0,48+0,2496
\end{aligned}
$$




$$
\begin{aligned}
& =0,7296 \\
\mathrm{CF}_{\text {combine }} & =0,7296+0,64 *(1-0,7296) \\
& =0,7296+0,1731 \\
& =0,9027 \\
\mathrm{CF}_{\text {combine }} & =0,9027+0,36 *(1-0,9027) \\
& =0,9027+0,035 \\
& =0,9377
\end{aligned}
$$

Hasil akhir untuk penyakit Layu Bakteri

c) Layu Fusarium

Perhitungan Kombinasi pada Penyakit Layu Fusarium dari Gejala Daun Tua Menguning dengan nilai kepercayaan 0,24 ; Tulang daun berwarna putih dengan nilai kepercayaan 0,64 ; Batang berwarna coklat dengan nilai kepercayaan 0,36 ; dan Tanaman layu keseluruhan dengan nilai kepercayaan 0,48 Dari gejala-gejala diatas pada penyakit Layu Fusarium menghasilkan perhitungan kombinasi dengan menggunakan rumus sebagai berikut :

$$
\begin{aligned}
\mathrm{CF}_{\text {combine }} & =\mathrm{CF}_{\text {old }}+\mathrm{CF}_{\text {gejala }}{ }^{*}\left(1-\mathrm{CF}_{\text {old }}\right) \\
\mathrm{CF}_{\text {combine }} & =0,24+0,64^{*}(1-0,24) \\
& =0,24+0,4864 \\
& =0,7264 \\
\mathrm{CF}_{\text {combine }} & =0,7264+0,36 *(1-0,7264) \\
& =0,7264+0,0984 \\
& =0,8284 \\
\mathrm{CF}_{\text {combine }} & =0,8284+0,48 *(1-0,8284) \\
& =0,8284+0,084 \\
& =0,9089
\end{aligned}
$$

Hasil akhir untuk penyakit Layu

Fusarium

d) Bercak Coklat Pada Daun

Perhitungan Kombinasi pada Penyakit Bercak coklat pada daun dari Gejala Bawah daun bercak putih dengan nilai kepercayaan 0,48 dan Batang berwarna coklat dengan nilai kepercayaan 0,36. Dari gejala diatas pada penyakit Bercak coklat pada daun menghasilkan perhitungan kombinasi dengan menggunakan rumus sebagai berikut :

$$
\begin{aligned}
\mathrm{CF}_{\text {combine }} & =\mathrm{CF}_{\text {old }}+\mathrm{CF}_{\text {gejala }}{ }^{*}\left(1-\mathrm{CF}_{\text {old }}\right) \\
\mathrm{CF}_{\text {combine }} & =0,48+0,36^{*}(1-0,48) \\
& =0,48+0,1872 \\
& =0,6672
\end{aligned}
$$

Hasil akhir untuk penyakit Bercak coklat pada daun

Dengan demikian maka Tanaman Cabai Keriting terserang penyakit Layu Bakteri dengan nilai Kepercayaan 0,9377. Persentasenya yaitu:

Nilai $\mathrm{CF}^{*} 100 \%=0,9377^{*} 100 \%=93,77 \%$

\section{b. Pengujian Validitas}

Pengujian validitas membandingkan hasil sistem dengan pendapat Pakar. Tabel 5, Tabel 6, Tabel 7 dan Tabel 8 merupakan rekapitulasi pengujian validitas.

a) Busuk Daun

Tabel 5. Selisih Posisi Busuk Daun

\begin{tabular}{|c|c|c|}
\hline Sistem & \multicolumn{1}{|c|}{$\begin{array}{c}\text { Pendapat } \\
\text { Pakar }\end{array}$} & $\begin{array}{c}\text { Selisih Posisi Sistem } \\
\text { Vs Pendapat Pakar }\end{array}$ \\
\hline $\begin{array}{c}\text { 1. Busuk } \\
\text { Daun }\end{array}$ & 1. Layu Bakteri & $|1-4|=3 \times 25 \%=75 \%$ \\
\hline $\begin{array}{c}\text { 2. Layu } \\
\text { Bakteri }\end{array}$ & 2. Layu Fusarium & $|2-1|=1 \times 25 \%=25 \%$ \\
\hline $\begin{array}{c}\text { 3. Layu } \\
\text { Fusarium }\end{array}$ & $\begin{array}{c}\text { 3. Bercak Coklat } \\
\text { Pada Daun }\end{array}$ & $|3-2|=1 \times 25 \%=25 \%$ \\
\hline $\begin{array}{c}\text { 4. Bercak } \\
\text { Coklat } \\
\text { Pada daun }\end{array}$ & 4. Busuk Daun & $|4-3|=1 \times 25 \%=25 \%$ \\
\hline & $\mathrm{AVcm}=\frac{150}{4}=37,5 \%$ \\
\hline
\end{tabular}

b) Layu Bakteri

Tabel 6. Selisih Posisi Layu Bakteri

\begin{tabular}{|l|l|l|}
\hline \multicolumn{1}{|c|}{ Sistem } & \multicolumn{1}{c|}{$\begin{array}{c}\text { Pendapat } \\
\text { Pakar }\end{array}$} & $\begin{array}{c}\text { Selisih Posisi Sistem } \\
\text { Vs Pendapat Pakar }\end{array}$ \\
\hline $\begin{array}{l}\text { 1. Busuk } \\
\text { Daun }\end{array}$ & 1. Layu Fusarium & $|1-3|=2 \times 25 \%=50 \%$ \\
\hline $\begin{array}{l}\text { 2. Layu } \\
\text { Bakteri }\end{array}$ & $\begin{array}{l}\text { 2. Bercak Coklat } \\
\text { Pada Daun }\end{array}$ & $|2-4|=2 \times 25 \%=50 \%$ \\
\hline $\begin{array}{l}\text { 3. Layu } \\
\text { Fusarium }\end{array}$ & 3. Busuk Daun & $|3-1|=2 \times 25 \%=50 \%$ \\
\hline $\begin{array}{l}\text { 4. Bercak } \\
\text { Coklat Pada } \\
\text { daun }\end{array}$ & 4. Layu Bakteri & $|4-2|=2 \times 25 \%=50 \%$ \\
\hline & & $\mathrm{AVcm}=\frac{200}{4}=50 \%$ \\
\hline
\end{tabular}

c) Layu Fusarium

Tabel 7.Selisih Posisi Layu Fusarium

\begin{tabular}{|l|l|l|}
\hline \multicolumn{1}{|c|}{ Sistem } & \multicolumn{1}{c|}{$\begin{array}{c}\text { Pendapat } \\
\text { Pakar }\end{array}$} & $\begin{array}{c}\text { Selisih Posisi Sistem } \\
\text { Vs Pendapat Pakar }\end{array}$ \\
\hline 1. Busuk Daun & $\begin{array}{l}\text { 1. Bercak } \\
\text { Coklat Pada } \\
\text { Daun }\end{array}$ & $|1-2|=1 \times 25 \%=25 \%$ \\
\hline 2. Layu Bakteri & 2. Busuk Daun & $|2-3|=1 \times 25 \%=25 \%$ \\
\hline $\begin{array}{l}\text { 3. Layu } \\
\text { Fusarium }\end{array}$ & 3. Layu Bakteri & $|3-4|=1 \times 25 \%=25 \%$ \\
\hline $\begin{array}{l}\text { 4. Bercak } \\
\text { Coklat Pada } \\
\text { daun }\end{array}$ & $\begin{array}{l}\text { 4. Layu } \\
\text { Fusarium }\end{array}$ & $|4-1|=3 \times 25 \%=75 \%$ \\
\hline & & $\mathrm{AVcm}=\frac{150}{4}=37,5 \%$ \\
\hline
\end{tabular}

d) Bercak Coklat Pada Daun.

Tabel 8. Selisih Posisi Bercak Coklat Pada

Daun

\begin{tabular}{|l|l|l|}
\hline \multicolumn{1}{|c|}{ Sistem } & \multicolumn{1}{c|}{$\begin{array}{c}\text { Pendapat } \\
\text { Pakar }\end{array}$} & $\begin{array}{c}\text { Selisih Posisi Sistem } \\
\text { Vs Pendapat Pakar }\end{array}$ \\
\hline 1. Busuk Daun & 1. Busuk Daun & $|1-1|=0 \times 25 \%=0 \%$ \\
\hline 2. Layu Bakteri & 2. Layu Bakteri & $|2-2|=0 \times 25 \%=0 \%$ \\
\hline $\begin{array}{l}\text { 3. Layu } \\
\text { Fusarium }\end{array}$ & $\begin{array}{l}\text { 3. Layu } \\
\text { Fusarium }\end{array}$ & $|3-3|=0 \times 25 \%=0 \%$ \\
\hline $\begin{array}{l}\text { 4. Bercak } \\
\text { Coklat Pada } \\
\text { daun }\end{array}$ & $\begin{array}{l}\text { 4. Bercak } \\
\text { Coklat Pada } \\
\text { Daun }\end{array}$ & $|4-4|=0 \times 25 \%=0 \%$ \\
\hline & & $A \bigvee c m=0 \%$ \\
\hline
\end{tabular}




\section{Penutup}

\subsection{Kesimpulan}

Kesimpulan yang dapat diambil dari pembuatan Sistem Pakar dalam Penerapan Metode Certainty Factor dalam Mendeteksi Penyakit Pada Cabai Keriting, adalah sebagai berikut:

1. Telah di rancang dan di bangun Sistem Pakar Penerapan Metode Certainty Factor dalam Mendeteksi Penyakit Pada Cabai Keriting.

2. Sistem yang dibangun dapat memberikan hasil indikasi penyakit berdasarkan pada gejala-gejala yang dipilih beserta tingkat keyakinannya. Penentuan jenis penyakit didasarkan pada nilai mb. Semakin besar nilai md dan semakin kecil nilai md, maka semakin besar pula potensi penyakit pada tanaman cabai keriting yang menyerang, begitu pula sebaliknya.

3. Berdasarkan pengujian validitas yang dilakukan oleh peneliti, berdasarkan perhitungan sistem dan berdasarkan perhitungan manual dengan memperoleh nilai CF tertinggi yang sama Pada penyakit Layu Bakteri dengan nilai persentase kepercayaan pada perhitungan validitas $50 \%$, dan pada perhitungan sistem $93,77 \%$. Sehingga sistem pendeteksian pada tanaman cabai keriting valid.

\subsection{Saran}

Saran yang dapat di berikan guna pengembangan sistem adalah sebagai berikut:

1. Sistem Pakar dikembangkan untuk diagnosa lanjut dengan penyakit tanaman cabai keriting dan gejala-gejala yang lebih kompleks dan detail. Dilengkapi dengan berbagai infromasi mengenai penyakit tanaman cabai kerting sehingga pengguna memahami betul akan penyakit yang menyerang tanaman.

2. Sistem pakar dikembangkan dengan menambahkan penyakit-penyakit yang lain, sehingga lebih luas pengetahuan para petani untuk mendeteksi penyakit yang menyerang tanaman cabai keriting.

\section{DAFTAR PUSTAKA}

[1] T. Winanto, Y. R. W. Utami, and S. H. Fitriasih, "Sistem Pakar Diagnosa Hama Dan Penyakit Tanaman Cabai Besar Menggunakan Metode Certainty Factor," J. Ilm. SINUS, vol. 15, no. 2, pp. 13-24, 2017, doi: 10.30646/sinus.v15i2.302.

[2] A. Ghofur, "Expert sistem mendeteksi hama pada tanaman cabai menggunakan metode certainty factor," NJCA, vol. 4, no. 2, pp. 127-135, 2019.

[3] Kusrini, Aplikasi Sistem Pakar Menentukan Kepastian Penggunaan dengan Metode Kualifikasi Pertanyaan. Yogyakarta: Penerbit ANDI, 2008.

[4] S. Yasita, "Sistem Pakar Penyakit Kulit Menggunakan Certainty Factor Berbasis Web. Jurnal Teknik Informatika Politeknik Caltex Riau," vol. Vol 1, 2012.

[5] D. M. L. Tobing, E. Pawan, F. E. Neno, and Kusrini, "Sistem Pakar Mendeteksi Penyakit Pada Tanaman Padi Menggunakan Metode Forward Chaining Expert System to Detect Disease Rice Plants Using Forward Chaining," J. IIm. SISFOTENIKA, vol. 9, no. 2, pp. 10-48, 2019.

[6] R. Hariyanto and K. Sa'diyah, "Sistem Pakar Diagnosis Penyakit dan Hama Pada Tanaman Tebu Menggunakan Metode Certainty Factor," JOINTECS (Journal Inf. Technol. Comput. Sci., vol. 3, no. 1, pp. 14, 2018, doi: 10.31328/jointecs.v3i1.500.

[7] Y. Setianto, B. Widada, and Y. W. U. Retno, "Sistem pakar untuk megetahui hama wereng pada tanaman padi beserta solusi dengan menggunakan logika fuzzy tsukamoto," J. TIKomSiN, vol. 5, no. 1, pp. 1-9, 2017.

[8] M. Arifin, S. Slamin, and W. E. Y. Retnani, "Penerapan Metode Certainty Factor Untuk Sistem Pakar Diagnosis Hama Dan Penyakit Pada Tanaman Tembakau," Berk. Sainstek, vol. 5, no. 1, p. 21, 2017, doi: 10.19184/bst.v5i1.5370.

[9] E. H. Wijaya and N. Hidayat, "Diagnosis Penyakit Cabai Dengan Menggunakan Metode Forward Chaining - DempsterShafer," vol. 2, no. 12, pp. 7202-7208, 2018. 